\section{Intermittent A.C. Arc Method for Spectrographic Analysis of Tantalum Oxide}

Spektrographische Analyse von Tantaloxid mit Hilfe eines intermittierenden Wechselstrombogens

Analyse von Tantaloxid; Spektralanalyse; intermitt. Wechselstrombogen

I.C. Chandola and R. Venkatasubramanian

Spectroscopy Division, Bhabha Atomic Research Centre Trombay, Bombay-400085, India

Received December 18, 1972; revised March 14, 1973

A spectrographic method has been developed to determine $\mathrm{Nb}$ and eleven other trace impurities simultaneously in tantalum oxide. The method does not involve any preparation of sample and is, therefore, simple and straightforward.

Standards are prepared by dry-mixing the spec-pure grade oxides with tantalum oxide supplied by Johnson Matthey and Co. Standards and samples are glued directly on to the flat tops of a pair of graphite electrodes (UCC 107) and excited by a Hilger's low voltage intermittent A.C. are source (Model FS 110) run at $6 \mathrm{~A}$ current. The spectra are

\section{Spectrophotometric Determination of Trace Amounts of Cobalt Using 7-Nitroso-8-hydroxyquinoline-5-sulphonic Acid as Reagent}

Spektrophotometrische Bestimmung von Kobaltspuren mit 7-Nitroso-8-hydroxychinolin-5-sulfonsäure

Best. von Kobalt mit 7-Nitroso-8-hydroxychinolin-5sulfonsäure; Spektralphotometrie

I. M. Issa and M. M. Aly

Chem. Dept., Faculty of Science, Assuit University Assuit, Egypt

Received August 9, 1972; revised December 27, 1972

It has been found that 7-Nitrose-8-hydroxyquinoline-5-sulphonic acid can be well employed for the spectrophotometric determination of traces of cobalt. Physicochemical investigation of the red complex formed showed its composition to be $\mathrm{H}\left[\mathrm{Co}(\mathrm{II}) \mathrm{L}_{3}\right]$ ( $\mathrm{L}=$ ligand) at $\mathrm{pH}$ 5.0. The molar absorptivity at $525 \mathrm{~nm}$ is $1.15 \times 10^{4} \mathrm{l} \cdot \mathrm{mole}^{-1} \cdot \mathrm{cm}^{-1}$, Beer's law is obeyed within the range of $0.9-12.0 \times 10^{-5}$ mole of $\mathrm{Co} / \mathrm{l}$. Absorption of the yellow NaHL or greenishbrown $\mathrm{Na}_{2} \mathrm{~L}$ did not effect the measurement at $525 \mathrm{~nm}$. photographed on Ilford N. 30 emulsion employing a JACO 3.4 metre grating spectrograph, in the first order of a 1200 grooves $/ \mathrm{mm}$ grating blazed at $3300 \AA$.

Two lines of matrix element Ta at $2808.86 \AA$ and $2943.77 \AA$, are selected as internal standards by the help of moving plate studies. $\mathrm{Nb}$ can be estimated in the range $40-4000 \mathrm{ppm}$ using the line $2950.87 \AA$. The analysis lines used and minimum amount estimated for other elements are: $\mathrm{Al} 3092.71 \AA 25 \mathrm{ppm}$ Fe $2966.9 \AA 10 \mathrm{ppm} ; \mathrm{Mn} 2801.06 \AA 2.5 \mathrm{ppm} ; \mathrm{Mo}$ $3112.12 \AA 30 \mathrm{ppm} ; \mathrm{Pb} 2833.06 \AA$ 5ppm; Ni3392.99 5 ppm; Si 2516.19 \& 12.5 ppm; Sn $3034.12 \AA 25$ ppm; Ti $3372.8 \AA 5$ ppm; V $3118.38 \AA 15$ ppm; Zr $3391.97 \AA$ $40 \mathrm{ppm}$. The sensitivity reported here is lowest for $\mathrm{Mo}, \mathrm{Ni}, \mathrm{Ti}$ and $\mathrm{V}$ and is comparable for other impurities with earlier methods.

The coefficient of variation ranges from $\pm 8 \%$ for $\mathrm{Nb}$ to $\pm 18 \%$ for Mo. Experiments showed that the recoveries were better than $85 \%$ of the elements added.

Mr. L.O. Chandola

Spectroscopy Division

Bhabha Atomic Research Centre

Modular Laboratories

Trombay, Bombay-400085

India

As the monosodium salt of the reagent is stable for only 3 days, it is advisable to use the disodium salt (at least 15 days). The presence of $\mathrm{Ca}, \mathrm{Sr}, \mathrm{Ba}, \mathrm{Cd}, \mathrm{Zn}$, $\mathrm{Mg}$, Th, $\mathrm{UO}_{2}, \mathrm{Zr}, \mathrm{W}$ in concentrations up to 150 times that of cobalt does not affect the results. Interference was observed for $\mathrm{Fe}, \mathrm{Mn}, \mathrm{Cr}$, even in about equal concentrations. Chloride, acetate, sulphate and nitrate up to $0.1 \mathrm{M}$ do not interfere. The sensitivity of the method is comparable to that of Nitroso-R-salt. As little as $0.6 \mathrm{ppm}$ of Co can be determined.

\section{Experimental}

Reagent. The monosodium salt of the reagent is prepared by nitrosation of 8-hydroxyquinoline-5-sulphonic acid in aqueous solution $\mathrm{pH} 5$ at $0^{\circ} \mathrm{C}$. The disodium salt is prepared by addition of the calculated amount of $\mathrm{NaOH}$ to the solution of NaHL.

Procedure. Mix $4.0 \mathrm{ml}$ of $0.2 \mathrm{M}$ acetate buffer $\mathrm{pH} 5$ with $2.0 \mathrm{ml}$ of the above reagent solution $(0.2 \mathrm{~g} / 100 \mathrm{ml})$ add an aliquot of the sample solution, make up to $8.0 \mathrm{ml}$ with water and shake. Measure the optical density at $525 \mathrm{~nm}$ against a blank solution. Take the results from a calibration curve prepared similarly.

Dr. M. M. Aly

Chem. Department, Facalty of Science

Assuit University, Assuit, Egypt 
Dünnschicht-chromatographische Trennung und Identifizierung einiger Diuretica (6-Chlor-7-sulfamyl-3,4-dihydrobenzo1,2,4-thiadiazin-1,1-dioxid, 2-Acetylamino1,3,4-thiadiazol-5-sulfonamid und 3-Cyclopentylmethyl-6-chlor7-sulfamyl-3,4-dihydrobenzo1,2,4-thiadiazin-1,1-dioxid) an unterschiedlichen Sorptionsschichten

Thin-Layer Chromatographic Separation and Identification of Some Diuretica on Different Sorption Layers

Trenn. von Diuretica; Chromatographie, Dünnschicht; unterschiedliche Schichten

H. Thielemann und M. Päpke

Eingegangen am 27. November 1972

Diuretica gehören verschiedenen Stoffklassen an und besitzen unterschiedliche Angriffspunkte.

Acetazolamid $[=$ Nephramid $=2$-Acetylamino1,3,4-thiadiazol-5-sulfonamid) zählt zu den Carboanhydrasehemmern mit größter Wirkung.

Hydrochlorothiazid $\quad(=$ Disalunil $=6$-Chlor-7sulfamyl-3,4-dihydrobenzo - 1,2,4-thiadiazin-1,1 - dioxid) und Cyclopenthiazid (=Benesal $=3$-Cyclopentylmethyl-6-chlor-7-sulfamyl-3,4-dihydrobenzo-1,2,4thiadiazin-1,1-dioxid) gehören zu den Saluretica.

Eine dünnschicht-chromatographische Trennung und Identifizierung der drei genannten Verbindungen kann von pharmazeutischem und toxikologischem Interesse sein.

\section{Experimenteller Teil}

Die dünnschicht-chromatographisch zu trennenden und zu identifizierenden Diuretica werden im folgenden unter der Kurzbezeichnung Substanz I, II und III aufgeführt. ( $\mathrm{I}=$ Acetazolamid; II = Hydrochlorothiazid; III = Cyclopenthiazid).

Verwendet man Fertigfolien $U V 254$ der Fa. Sklárny Kavalier (ČSSR) (Zusammensetzung der Folien: Sorptions- mittel: Kieselgel für Chromatographie mit einem Luminescenzindicator; Unterlage: Verfestigte Aluminiumfolie; Bindemittel: Stärke) und ein Laufmittelmittelsystem, das für alle Sorptionsschichten gleichermaßen diente, bestehend aus n-Butanol/Methanol/Chloroform $/ 25 \%$ ig. Ammoniak (40:15:15:15), so ließen sich nach Lufttrocknung der Folien und Betrachten unter langwelligem UV-Licht (Filter) die Substanzen I und II an der Eigenfluorescenz erkennen.

Als Sprühreagens eignete sich auch Rhodamin $B(0,025 \%$ ige Lösung in Äthanol) und nach anschließendem Betrachten der Folien im langwelligen UV-Licht kann man die Substanzen I und II als dunkelviolette Flecke auf rosa Untergrund erkennen.

$h_{\mathrm{p}}$-Werte: Substanz I 21, Substanz II 47.

Mit dem Sprühreagens Natriumnitrosopentacyanoferrat(III) ließen sich alle 3 Verbindungen deutlich fixieren. $h_{\mathrm{I}}$-Werte: SubstanzI 21, SubstanzII 47, SubstanzIII 2. Auch eignete sich eine Silbernitrat-Fluorescein-Lösung.

Herstellung der Lösung: a) Silbernitratlösung ( $10 \%$ in Wasser); b) 0,2 g Fluorescein-Natrium werden zu $100 \mathrm{ml}$ in absol. Äthanol gelöst.

Als Nachweisreagens müssen vor Gebrauch $10 \mathrm{ml}$ der Lösung a) mit $50 \mathrm{ml}$ der Lösung b) gemischt werden.

Trennung und Nachweis an Celluloseschichten.

Herstellung der Celluloseplatten: Zur Verfügung stand Cellulosepulver zur Dünnschicht-Chromatographie FND Filtrak der Spezialfabrik Niederschlag des VEB Freiberger Zellstoff- und Papierfabrik zu Weißenborn.

$30 \mathrm{~g}$ Pulver werden in einem Becherglas mit $60 \mathrm{ml}$ Wasser (ausreichend für 5 Platten $20 \times 20 \mathrm{~cm}$ ) $30-40 \mathrm{sec}$ mit einem elektrischen Rührer aufgeschlagen und dann auf die Platten verstrichen. Die luftgetrockneten Platten eignen sich vortrefflich zur Trennung und Identifizierung. Die Identifizierung der Verbindungen erfolgt in Jod-Dampf-Atmosphäre und anschließend kurze Behandlung durch schwaches Erwärmen im Trockenschrank bei $50^{\circ} \mathrm{C}$. Man erkennt deutlich gelb-braune Flecke.

$\mathrm{hR}_{\mathrm{r}}$-Werte: SubstanzI 18, SubstanzII 32, SubstanzIII 8. Unter langwelligem UV-Licht (Filter) sind nur die Substanzen I und II mit violetter Fluorescenz erkennbar.

Trennung und Nachweis an Mischschichten (Kieselgel G und Cellulose 1:1).

Die Platten werden bei $110^{\circ} \mathrm{C} 2 \mathrm{~h}$ im Trockenschrank aktiviert und danach unmittelbar verwendet.

Nach Joddampflokalisation konnten die $\mathrm{hR}_{\mathrm{f}}$-Werte markiert werden. Substanz I 19, Substanz II 44, Substanz III 2.

Dr. rer. nat. H. Thielemann

Apothekerin M. Päpke

DDR-36 Halberstadt, Wasserturmstraße 10

Deutsche Demokratische Republik 